\title{
INVESTIGATION ON THE RACE COMPOSITION OF DOWNY MILDEW (Plasmopara halstedii Farl. Berlese et de Tony) IN BULGARIA DURING 2007-2008
}

\author{
Shindrova, P.
}

Dobroudja Agricultural Institute - General Toshevo, Bulgaria

Received: August 03, 2009

Accepted: November 10, 2009

\begin{abstract}
SUMMARY
The climatic changes during the recent years and the general usage in the agricultural practice of resistant varieties and hybrids are the main reasons for the limited distribution of downy mildew on sunflower (Plasmopara halstedii Farl. Berlese ét de Toni) in Bulgaria. The disease has occurrence only in separate locations, with a low percentage of attack - up to $10 \%$. Our investigations showed that the current situation stimulated the pathogen to develop new races. Thus, for example, during 1988-2000, i.e., over a period of 12 years, only two downy mildew races were identified in Bulgaria. Now, however, there are five: $300,330,700,721$, and 731 . Race 700 has the largest area of occurrence. This race has been isolated from 20 samples with origin from northern Bulgaria during the years of investigation. Its percentage in the downy mildew population was $45.5 \%$, and it is of the greatest economic significance for sunflower production in this part of the country. Races 721 and 731 were isolated in the last two years. They had equal percentages in the population - $15.9 \%$ each, but their area of occurrence was quite different. Race 721 was distributed in south-east Bulgaria, its range of occurrence was large, and it is the most significant race in this region in economic terms. The other new race, 731, was localized only in the region of the Dobroudja Agricultural Institute (DAI) and has currently no economic significance for sunflower production. Race 330 is also a new one for Bulgaria. It was isolated in 2006 in single fields in north Bulgaria and its percentage in the population was $13.6 \%$. Race 300 had the most limited distribution during the last two years $-9.1 \%$. This tendency has been observed for the last few years and most probably race 300 will soon disappear from the downy mildew population.
\end{abstract}

Key words: downy mildew, races composition

\section{INTRODUCTION}

In recent years, a limited distribution of downy mildew on sunflower (Plasmopara halstedii Farl. Berlese ét de Toni) has been observed in Bulgaria. The pathogen occurs only in separate areas with more specific climate conditions and with a low attack rate - up to $10 \%$. This can be explained by the global climatic 
changes and the use of fungicides, on the one hand, and the mass growing of resistant varieties and hybrids, on the other. Such conditions, which are unfavorable for the pathogen, cause more intensive physiological changes in the species not only in Bulgaria but in other countries as well.

Rozynek and Spring (2000) investigated pathotypes of sunflower downy mildew in the southern parts of Germany. They identified pathotypes 730, 710, 330, 310 and 300 in this region. Using DNA analysis of samples with different origin, it was found that the pathotypes 700, 701, 703, 710 and 730 from Slovakia, France and Germany were of recent origin and that they were highly aggressive physiological races (Spring et al., 2006). As reported by Antonova et al. (2008), seven races of Plasmopara halstedii have been identified in the region of Northern Caucasus during the last four years - 100, 300, 310, 330, 700, 710 and 730. At present, the main race, which is widely distributed everywhere in the studied territories, is 330. Economically important in these territories are races 330, 710 and 730 .

Our investigations also showed that the current situation stimulated the pathogen to form new races faster. During 1988-2000, i.e. over a period of 12 years, only two races had been identified in Bulgaria - race 1 and race 2, which correspond to races 100 and 300 of the new nomenclature (Shindrova, 1992; 1995; 1998; 2000). From 2001 to 2004, the race variability of the pathogen changed, as race 700 was isolated. During 2004-2006, the downy mildew population was enriched with a new race - 330 (Shindrova, 2005; 2006). Our observations during the last two years revealed that the process of accelerated formation of races in the population was in progress. This was confirmed also by the results from the present investigation.

\section{MATERIALS AND METHODS}

In order to determine the race variability of sunflower downy mildew in the major sunflower production regions in Bulgaria, field expeditions for collecting isolates of Plasmopara halstedii were organized in 2007 and 2008. Leaves from systemically infected plants were collected and used as inoculum. During the period of investigations the inoculum used originated from:

- 2007 - south-eastern Bulgaria (Kozarevo, Svoboden, Gorsky izvor); northwestern Bulgaria (Chomakovtzy, Kneja, Selanovtzy); central-northern Bulgaria (Pordim, Svishtov, Russe, Byala ); north-eastern Bulgaria (Silistra, DAI/1, DAI/2).

- 2008 - south-eastern Bulgaria (Stambolijsky/1, Stambolijsky/2, Orlovo, Radnevo/1, Radnevo/2, Dinya, Kovach); central-southern Bulgaria (Ognianovo); central-northern Bulgaria (Borovan, Pordim/1, Pordim/2, Piperkovo, Garvan); north-eastern Bulgaria (Silistra, Karapelit, Senokos, Dolina, Dropla, DAI/1, DAI/2, DAI/3, DAI/4, DAI/5, DAI/6, DAI/7, DAI/8, DAI/9, DAI/10, DAI/1 1, DAI/ $12, \mathrm{DAI} / 13)$.

The inoculum collected from the above regions was used to infect the differential set lines applying the standard methodology (Gulia et al., 1991). For identifica- 
tion of the race affiliation of downy mildew according to the new nomenclature system, nine lines were used. These were grouped as follows:

- First group - AD-66 (D-1), Rha-265 (D-2), Rha-274 (D-3);

- Second group - PM-13 (D-4), PM-17 (D-5), 803-1 (D-6);

- Third group - HAR-4 (D-7), HAR-5 (D-8), HA-335 (D-9).

The race was identified on the basis of the response of the lines from each group (Gulya et al., 1998).

\section{RESULTS AND DISCUSSION}

During the first year of the investigation 13 plant samples were collected and processed. They originated from the main sunflower production areas of the country: south-east, north-west, central north and north-east Bulgaria (Table 1).

Table 1: Distribution and race composition of downy mildew in sunflower during 2007

\begin{tabular}{|c|c|c|c|c|c|c|c|c|c|c|}
\hline \multirow{3}{*}{ Origin 2007} & \multicolumn{3}{|c|}{ Set one } & \multicolumn{3}{|c|}{ Set two } & \multicolumn{3}{|c|}{ Set three } & \multirow{3}{*}{$\begin{array}{l}\text { Race } \\
\mathrm{N}\end{array}$} \\
\hline & $\overline{D-1}$ & D-2 & $\overline{D-3}$ & $\mathrm{D}-4$ & D-5 & $\mathrm{D}-6$ & $\overline{D-7}$ & D-8 & D-9 & \\
\hline & \multirow{2}{*}{ HA 304} & Rha 26 & ha 274 & DM 2 & PM 17 & $803-1$ & HAR 4 & HAR 5 & HA 335 & \\
\hline \multicolumn{10}{|c|}{$\begin{array}{l}\text { South-eastern Bulgaria } \\
\end{array}$} & \\
\hline Kozarevo & $S$ & $\mathrm{~S}$ & S & $\mathrm{R}$ & $\mathrm{S}$ & $\mathrm{R}$ & $\mathrm{S}$ & $\mathrm{R}$ & $\mathrm{R}$ & 721 \\
\hline Svoboden & S & S & S & $\mathrm{R}$ & S & $\mathrm{R}$ & S & $\mathrm{R}$ & $\mathrm{R}$ & 721 \\
\hline Gorsky izvor & S & S & S & $\mathrm{R}$ & S & $\mathrm{R}$ & S & $\mathrm{R}$ & $\mathrm{R}$ & 721 \\
\hline \multicolumn{11}{|c|}{ North-west Bulgaria } \\
\hline Chomakovtzy & $S$ & $S$ & $\mathrm{R}$ & $\mathrm{s}$ & $S$ & $\mathrm{R}$ & $\mathrm{R}$ & $\mathrm{R}$ & $\mathrm{R}$ & 330 \\
\hline Knezha & $S$ & $S$ & S & $\mathrm{R}$ & $\mathrm{R}$ & $\mathrm{R}$ & $\mathrm{R}$ & $\mathrm{R}$ & $\mathrm{R}$ & 700 \\
\hline Selanovtzy & S & S & $\mathrm{R}$ & $\mathrm{R}$ & $\mathrm{R}$ & $\mathrm{R}$ & $\mathrm{R}$ & $\mathrm{R}$ & $\mathrm{R}$ & 300 \\
\hline \multicolumn{11}{|c|}{ North Bulgaria } \\
\hline Pordim & $S$ & $S$ & S & $\mathrm{R}$ & $\mathrm{R}$ & $\mathrm{R}$ & $\mathrm{R}$ & $\mathrm{R}$ & $\mathrm{R}$ & 700 \\
\hline Svishtov & $S$ & $S$ & S & $\mathrm{R}$ & $\mathrm{R}$ & $\mathrm{R}$ & $\mathrm{R}$ & $\mathrm{R}$ & $\mathrm{R}$ & 700 \\
\hline Russe & s & S & s & $\mathrm{R}$ & $\mathrm{R}$ & $R$ & $\mathrm{R}$ & $\mathrm{R}$ & $\mathrm{R}$ & 700 \\
\hline Byala & $S$ & $S$ & $\mathrm{~S}$ & $\mathrm{R}$ & $\mathrm{R}$ & $\mathrm{R}$ & $\mathrm{R}$ & $\mathrm{R}$ & $\mathrm{R}$ & 700 \\
\hline \multicolumn{11}{|c|}{ North-east Bulgaria } \\
\hline Silistra & $S$ & $S$ & S & $\mathrm{R}$ & $\mathrm{R}$ & $\mathrm{R}$ & $\mathrm{R}$ & $\mathrm{R}$ & $\mathrm{R}$ & 700 \\
\hline $\mathrm{DAl} / 1$ & S & S & $S$ & $\mathrm{R}$ & $R$ & $R$ & $\mathrm{R}$ & $\mathrm{R}$ & $\mathrm{R}$ & 700 \\
\hline $\mathrm{DAl} / 2$ & $S$ & $S$ & $\mathrm{R}$ & $S$ & $S$ & $\mathrm{R}$ & $\mathrm{R}$ & $\mathrm{R}$ & $\mathrm{R}$ & 330 \\
\hline
\end{tabular}

S-sensitive; R-resistant

The small number of samples was due to the climatic conditions, which were unfavorable for the development of downy mildew. The results from this investigations showed that from the 13 samples collected and analyzed in 2007, 4 races (pathotypes) were isolated - 300, 330, 700, 721. Race 721 was new for Bulgaria. It was isolated from three samples originating from south-east Bulgaria. The fact that the race was identified in three locations at considerable distance from one another indicated that although this pathotype was a new one in Bulgaria, it had a wide area of distribution and a significant percentage in the downy mildew population $-23.1 \%$ 
(Table 3). This fact allows the assumption that the race was probably formed earlier but was not isolated when analyzing the samples. Race 700 had the highest percentage $-53.8 \%$. It was identified in 7 origins located mainly in the region of central north and north-east Bulgaria. Races 330 (15.4\%) and $300(7.7 \%)$ had a more limited distribution in the downy mildew population in 2007; they were isolated from 3 samples with origin from north Bulgaria.

Table 2: Distribution and race composition of downy mildew in sunflower during 2008

\begin{tabular}{|c|c|c|c|c|c|c|c|c|c|c|}
\hline \multirow{3}{*}{ Origin 2008} & \multicolumn{3}{|c|}{ Set one } & \multicolumn{3}{|c|}{ Set two } & \multicolumn{3}{|c|}{ Set three } & \multirow{3}{*}{$\begin{array}{l}\text { Race } \\
\mathrm{N}\end{array}$} \\
\hline & $\mathrm{D}-1$ & $\mathrm{D}-2$ & $\mathrm{D}-3$ & $\mathrm{D}-4$ & $\mathrm{D}-5$ & $\mathrm{D}-6$ & $\mathrm{D}-7$ & $\mathrm{D}-8$ & D-9 & \\
\hline & $\overline{\mathrm{HA}-89}$ & Rha-265 & Rha-274 & DM-2 & PM17 & $803-1$ & HAR-4 & HAR-5 & HA-335 & \\
\hline \multicolumn{11}{|c|}{ South-east Bulgaria } \\
\hline Stamboliyski/1 & $\mathrm{s}$ & S & $\mathrm{s}$ & $\mathrm{R}$ & $\mathrm{R}$ & $\mathrm{R}$ & $\mathrm{R}$ & $\mathrm{R}$ & $\mathrm{R}$ & 700 \\
\hline Stamboliyski/2 & s & S & $\mathrm{R}$ & $\mathrm{R}$ & $\mathrm{R}$ & $\mathrm{R}$ & $\mathrm{R}$ & $\mathrm{R}$ & $\mathrm{R}$ & 300 \\
\hline Orlovo & $S$ & S & $\mathrm{R}$ & $\mathrm{R}$ & $\mathrm{R}$ & $\mathrm{R}$ & $R$ & $R$ & $R$ & 300 \\
\hline Radnevo/1 & $S$ & S & $S$ & $\mathrm{R}$ & S & $\mathrm{R}$ & S & $\mathrm{R}$ & $\mathrm{R}$ & 721 \\
\hline Radnevo/2 & $S$ & $S$ & $S$ & $\mathrm{R}$ & $S$ & $\mathrm{R}$ & $S$ & $\mathrm{R}$ & R & 721 \\
\hline Dinya & $S$ & $S$ & $S$ & $\mathrm{R}$ & S & $\mathrm{R}$ & S & $R$ & $R$ & 721 \\
\hline Kovach & $S$ & $S$ & $S$ & $\mathrm{R}$ & S & $\mathrm{R}$ & S & $\mathrm{R}$ & $\mathrm{R}$ & 721 \\
\hline \multicolumn{11}{|c|}{ South Bulgaria } \\
\hline Ognyanovo & $\mathrm{s}$ & $\mathrm{s}$ & $\mathrm{R}$ & $\mathrm{R}$ & $\mathrm{R}$ & $\mathrm{R}$ & $\mathrm{R}$ & $\mathrm{R}$ & $\mathrm{R}$ & 300 \\
\hline \multicolumn{11}{|c|}{ North Bulgaria } \\
\hline Borovan & $\mathrm{s}$ & $\mathrm{s}$ & $\mathrm{s}$ & $\mathrm{R}$ & $\mathrm{R}$ & $\mathrm{R}$ & $\mathrm{R}$ & $\mathrm{R}$ & $\mathrm{R}$ & 700 \\
\hline Pordim/1 & $S$ & $S$ & $S$ & $\mathrm{R}$ & $\mathrm{R}$ & $\mathrm{R}$ & $\mathrm{R}$ & $\mathrm{R}$ & $\mathrm{R}$ & 700 \\
\hline Pordim/2 & $S$ & S & $S$ & $\mathrm{R}$ & $\mathrm{R}$ & $\mathrm{R}$ & $R$ & $R$ & $R$ & 700 \\
\hline Piperkovo & $S$ & $S$ & $\mathrm{R}$ & $S$ & $S$ & $\mathrm{R}$ & $\mathrm{R}$ & $\mathrm{R}$ & $\mathrm{R}$ & 330 \\
\hline Garvan & $S$ & S & $\mathrm{R}$ & $S$ & $S$ & $\mathrm{R}$ & $\mathrm{R}$ & $\mathrm{R}$ & $\mathrm{R}$ & 330 \\
\hline \multicolumn{11}{|c|}{ North-east Bulgaria } \\
\hline Silistra & $\mathrm{s}$ & $S$ & S & $S$ & $\mathrm{R}$ & $\mathrm{R}$ & $\mathrm{R}$ & R & R & 700 \\
\hline Karapelit & $S$ & S & S & $\mathrm{R}$ & $\mathrm{R}$ & $\mathrm{R}$ & $\mathrm{R}$ & $\mathrm{R}$ & $\mathrm{R}$ & 700 \\
\hline Senokos & $S$ & S & $S$ & $\mathrm{R}$ & $\mathrm{R}$ & $\mathrm{R}$ & $\mathrm{R}$ & $\mathrm{R}$ & $\mathrm{R}$ & 700 \\
\hline Dolina & $S$ & $S$ & $\mathrm{R}$ & $S$ & $S$ & $\mathrm{R}$ & $\mathrm{R}$ & $\mathrm{R}$ & R & 330 \\
\hline Dropla & $S$ & S & $S$ & $\mathrm{R}$ & $\mathrm{R}$ & $\mathrm{R}$ & $\mathrm{R}$ & $\mathrm{R}$ & $\mathrm{R}$ & 700 \\
\hline $\mathrm{DAl} / 1$ & $S$ & $S$ & $S$ & $S$ & $S$ & $\mathrm{R}$ & S & $\mathrm{R}$ & $\mathrm{R}$ & 731 \\
\hline $\mathrm{DAl} / 2$ & S & S & S & $\mathrm{R}$ & $\mathrm{R}$ & $\mathrm{R}$ & $\mathrm{R}$ & $R$ & $R$ & 700 \\
\hline $\mathrm{DAl} / 3$ & $S$ & $S$ & $S$ & $\mathrm{R}$ & $\mathrm{R}$ & $\mathrm{R}$ & $\mathrm{R}$ & $\mathrm{R}$ & $\mathrm{R}$ & 700 \\
\hline $\mathrm{DAl} / 4$ & $S$ & $S$ & $S$ & $\mathrm{R}$ & $\mathrm{R}$ & $\mathrm{R}$ & $S$ & $\mathrm{R}$ & $\mathrm{R}$ & 731 \\
\hline $\mathrm{DAl} / 5$ & $S$ & $S$ & R & $S$ & $S$ & $\mathrm{R}$ & $\mathrm{R}$ & $\mathrm{R}$ & $\mathrm{R}$ & 330 \\
\hline $\mathrm{DAl} / 6$ & $S$ & $S$ & $S$ & $S$ & $S$ & $\mathrm{R}$ & $S$ & R & R & 731 \\
\hline $\mathrm{DAl} / 7$ & $S$ & $S$ & $S$ & $S$ & $S$ & $\mathrm{R}$ & $S$ & $R$ & $R$ & 731 \\
\hline $\mathrm{DAl} / 8$ & $S$ & $S$ & $S$ & $\mathrm{R}$ & $\mathrm{R}$ & $\mathrm{R}$ & $\mathrm{R}$ & $\mathrm{R}$ & $\mathrm{R}$ & 700 \\
\hline $\mathrm{DAl} / 9$ & $S$ & $S$ & $S$ & $\mathrm{R}$ & $\mathrm{R}$ & $\mathrm{R}$ & $\mathrm{R}$ & R & $\mathrm{R}$ & 700 \\
\hline $\mathrm{DAl} / 10$ & $S$ & $S$ & $S$ & $S$ & $S$ & $\mathrm{R}$ & $S$ & $\mathrm{R}$ & $\mathrm{R}$ & 731 \\
\hline $\mathrm{DAl} / 11$ & $S$ & $S$ & $S$ & $\mathrm{R}$ & $\mathrm{R}$ & $\mathrm{R}$ & $\mathrm{R}$ & $\mathrm{R}$ & $\mathrm{R}$ & 700 \\
\hline $\mathrm{DAl} / 12$ & $S$ & $S$ & $S$ & $S$ & $S$ & $\mathrm{R}$ & S & $\mathrm{R}$ & $\mathrm{R}$ & 731 \\
\hline $\mathrm{DAl} / 13$ & $S$ & $S$ & $S$ & $S$ & $S$ & $\mathrm{R}$ & $S$ & $\mathrm{R}$ & $\mathrm{R}$ & 731 \\
\hline
\end{tabular}


In the 2008 growing season, the climatic conditions were comparatively more favorable for the development of downy mildew on sunflower, especially in the regions of south-east and north-east Bulgaria. The number of collected samples was higher than in the previous year, as 31 samples were collected (Table 2). This allowed us to complete the results obtained in the previous year and to obtain a clearer picture of the race composition and distribution of downy mildew for the period of investigation. The data in Table 2 show that the following year a new race in Bulgaria was found, identified as race 731. It was isolated from samples with origin from the region of DAI - mainly from breeding fields and materials from international exchange. This race was the most virulent. One of the explanations for the occurrence of the new race in this very location can be the high breeding pressure on the pathogen, because in the breeding fields resistant genotypes are predominantly grown. On the other hand, this may have been due to the intensive international exchange of breeding materials, which makes possible the transfer of the fungus, mainly through infected seeds, plant residues or soil particles. Besides race 731, four more pathotypes were isolated in 2008: 300, 330, 700 and 721. Race 700 was distributed on the largest area. The race was identified in all sunflower production regions and represented $42.0 \%$ of the pathogen population. A significant percentage (12.9\%) belonged to another new race -721 . This race was localized in the region of south-east Bulgaria. The other two pathotypes had a more limited distribution $-12.9 \%$ for race 330 and $9.7 \%$ for race 300 .

Table 3: Percentage of different races in the downy mildew population

\begin{tabular}{lcccccc}
\hline & \multicolumn{7}{c}{ Period of study } \\
\cline { 2 - 7 } Races & \multicolumn{2}{c}{2007} & \multicolumn{2}{c}{2008} & \multicolumn{2}{c}{$2007-2008$} \\
\cline { 2 - 7 } & \multicolumn{7}{c}{ Collected samples } \\
\cline { 2 - 7 } & 1 & 7.7 & 3 & 9.7 & 4 & $\%$ \\
\hline 300 & 2 & 15.4 & 4 & 12.9 & 6 & 13.6 \\
330 & 7 & 53.8 & 13 & 42.0 & 20 & 45.5 \\
700 & 3 & 23.1 & 4 & 12.9 & 7 & 15.9 \\
721 & - & - & 7 & 22.5 & 7 & 15.9 \\
731 & 13 & 100 & 31 & 100 & 44 & 100 \\
$300+330+700+721+731$ & 13 &
\end{tabular}

\section{CONCLUSIONS}

It can be concluded that during the period 2007-2008 five pathotypes of downy mildew occurred in Bulgaria - races 300, 330, 700, 721 and 731. Their distribution and incidence are closely related to both the climatic conditions of the year and the resistance of the varieties and hybrids used in agricultural practice. Race 700 had the largest area of distribution. This race was isolated from 20 samples during the years of investigation with origin from north Bulgaria. Its percentage in the downy mildew population was $45.5 \%$ and it was of the greatest significance for sunflower 
production in this part of the country. Races 721 and 731 were isolated in the last two years. They had equal percentages in the pathogen population - $15.9 \%$ each, but their area of occurrence was quite different. Race 721 was distributed in south-east Bulgaria and was identified within a wide range, with its economic significance in this region being the highest. The other new race, 731 , was localized only in the breeding fields of DAI (north-east Bulgaria) and currently has no economic significance for sunflower production. Race 330 was also a new one, having been isolated in 2006. It was of limited occurrence during the last two years, its percentage in the population being $13.6 \%$. Race 300 had the most limited distribution during the last two years $-9.1 \%$, which due to the cultivation of resistant varieties and hybrids. This tendency has been observed for the last few years and most probably race 300 will soon disappear from the downy mildew population.

\section{REFERENCES}

Antonova, T., Iwebor, M. and Araslanova, N., 2008. Races of Plasmopara halstedii on sunflower in separate agrocenoses of Adigeya Republic, Krasnodar and Rostov regions in Russia. $17^{\text {th }}$ International Sunflower Conference, Vol. 1, Cordoba, Spain June 8-12, pp. 85-96.

Gulya, T.J., Miler, J.F., Firanyi, F. and Sackston, W.E., 1991. Proposed internationally standardized method for race identification of Plasmopara halstedii. Helia 14: 11-20.

Gulya, T.J., Tourvielle de la Brouhe, D., Maširević, S., Penaud, A., Rashid, K., Viranyi, F., 1998. Proposal for standardized nomenclature and identification of races of Plasmopara halstedii (sunflower downy mildew). ISA Symposium III: Sunflower downy mildew, Fargo (ND, USA) 13-14 January, pp. 130-136.

Gulya, T.J., Miler, J.F., Viranyi, F. and Sackston, W.E., 1991. Proposed internationally standardized method for race identification of Plasmopara halstedii. Helia 14: 11-20.

Spring, O., Bachofer, M., Thines, M., Rienthmuller, A., Goker, M. and Obervinkler, F., 2006. Interspecific Relationship of Plasmopara halstedii Isolates Differing in Pathogenicity and Geographic Origin on ITS Sequence Data. European Journal of Plant Pathology, Vol. 14, Number 3/ March (Abstract).

Rozynek, B., Spring, O., 2000. Pathotypes of sunflower downy mildew in southern parts of Germany. Helia 23(32): 27-34.

Shindrova, P., 1992. Race composition of downy mildew (Plasmopara helianthi Novot.) in Bulgaria during the period 1988-1990. Plant Science, Vol. XXIX, N 7-8, Sofia, pp. 118122 .

Shindrova, P., 1995. Race composition of downy mildew (Plasmopara helianthi Novot.) in Bulgaria during the period 1991-1994. The first Balkan Simposium on breeding and cultivation of wheat, sunflower and legume crops, Albena, Bulgaria, pp. 345-348.

Shindrova, P., 1998. Distribution and race composition of downy mildew (Plasmopara halstedii) in Bulgaria in the period 1995-1997. $7^{\text {th }}$ International Congress of Plant Pathology, Edinburgh, Scotland, 9-16 August 1998. (Downy Mildew Newsletter, Number 10, August 1998, pp. 16).

Shindrova, P.S., 2000, Distribution and race composition of downy mildew (Plasmopara halstedii (Farl.) Berl. and de Toni) in Bulgaria. Helia 23(33): 25-32.

Shindrova, P., 2005. New nomenclature of downy mildew races in sunflower (Plasmopara halstedii (Farl.) Berlese et de Toni) in Bulgaria (Race composition during 2000-2003). Helia 28(42): 57-64.

Shindrova, P., 2006. Downy mildew (Plasmopara halstedii (Farl.) Berlese et de Tony) distribution and race composition during 2004-2006. $70^{\text {th }}$ Anniversary of Plant Protection Institute and Annual Balkan Week of Plant Health-Plant Protection Institute, May 2831, 2006, Kostinbrod, Bulgaria-Book of Abstracts, pp. 22. 